Arhe XVIII, 35/2021

UDK 13 Kant I.

101

130.11

DOI https://doi.org/10.19090/arhe.2021.35.31-48

Originalni naučni rad

Original Scientific Article

\author{
MINA ĐIKANOVIĆ 1 \\ Univerzitet u Novom Sadu, Filozofski fakultet
}

\title{
PROBLEM TREĆE ANTINOMIJE
}

Sažetak: U tekstu se istražuje način na koji je Kant nastojao da okonča viševekovnu diskusiju o odnosu između prirode i slobode. Uz paralogizme i ideal, antinomije predstavljaju „sofizme čistog uma“. Tzv. treća antinomija izlaže sukob oprečnih pogleda na odnos između prirode i slobode, odnosno, nužnosti i slobode. Kant smatra da će podvajanjem sveta otkriti mogući prostor za čovekovu slobodu i pokazati da se treća antinomija sama od sebe razrešava na način koji nije poguban po zbilju.

Ključne reči: Kant, antinomija, sloboda, priroda, um, kauzalitet

U trećoj antinomiji teza glasi: „Kauzalitet na osnovu zakona prirode nije jedini kauzalitet na osnovu koga se mogu objašnjavati sve pojave sveta. Radi njihova objašnjenja mora da se pretpostavi još jedan kauzalitet na osnovu slobode“, a antiteza: „Ne postoji nikakva sloboda, već se sve u svetu

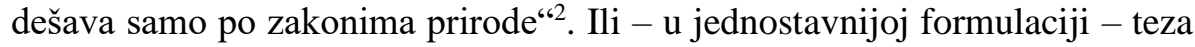
glasi: „U svetu postoje slobodni uzroci“, a antiteza: „Nema slobode, sve je priroda“"3.

\footnotetext{
${ }^{1}$ E-mail adresa autorke: mina.djikanovic@ff.uns.ac.rs

${ }^{2}$ Kant, I., Kritika čistoga uma, Dereta, Beograd 2003, str. 250-251.

${ }^{3}$ Kant, I., Prolegomena za svaku buduću metafiziku, Plato, Beograd 2005, par. 51, str. 90. Satz: Es gibt in der Welt Ursachen durch Freiheit. Gegensatz: Es ist keine Freiheit, sondern alles ist Natur (Kant, I., Prolegomena zur einer jeden künftigen Metaphysik, die als Wissenschaft wird auftreten können, Werke in zwölf Banden, Bd. 5, par. 51, S. 211). Zapravo, uzroci putem slobode ili kroz slobodu, a ne slobodni uzroci. „Slobodni uzroci“ podrazumevali bi prevashodno negativnost određenja, dok
} 
Bez obzira što filozofija zahteva da se, prema poznatoj Hegelovoj primedbi, ,plivanju učimo dok smo u vodi“ - što u velikoj meri otežava zadatak nekakvog uvođenja u filozofiju koje bi bilo ne-još-filozofsko veoma je teško, ako ne i nemoguće, obraditi jednu filozofsku temu ili problem posredstvom pristupa in medias res. Naslov teksta usmerava ka konkretnom problemu, ali taj konkretni problem - pogotovo u filozofijama koje pretenduju na sistemski karakter - nužno izvire iz čitavog niza međusobno povezanih sklopova mišljenja. Na ovom mestu nas interesuje problem Kantove „treće antinomije“, ali način na koji je tekst započet pretpostavlja, čak zahteva, veoma informisanog čitaoca. Taj čitalac zna barem nekoliko osnovnih stvari koje mu omogućuju da kontekstualizuje treću antinomiju. Recimo, zna da se uz Kantovu filozofiju po pravilu dodaje epitet revolucionarna, da se govori o prekretnici i kopernikanskom obrtu. Jasno je tom čitaocu da taj kopernikanski obrt podrazumeva da predmetom spoznaje postaje sama spoznaja, a - ako je malo upućeniji - zna da kopernikanski obrt i zasnivanje transcendentalne filozofije ne pripadaju tzv. gnoseološkoj strani filozofije u izvornom, već u izvedenom smislu. U svom intrinzičnom značenju, projekat transcendentalne filozofije jeste projekat slobode. Nije našem čitaocu strano distingviranje fenomenalnog i noumenalnog sveta niti posledice takvog rasapa. Informisani čitalac, takođe, zna da Kant govori o razumu i čulnosti kao jednako značajnim elementima svakog iskustva, prevazilazeći na taj način novovekovni sukob racionalizma i empirizma. U pola noći će umeti da izrecituje da su misli bez sadržaja prazne, a opažaji bez pojmova slepi. Zna i da um, kao treća duševna moć, ne učestvuje u iskustvu, ali ima drugu ulogu koja će čoveka odrediti kao prevashodno praktičko biće. Pored toga, taj veoma upućeni čitalac svestan je da svaka od ovih duševnih moći ima svoje apriorne forme - što znači da mu je poznata i razlika između apriornog $\mathrm{i}$ aposteriornog, analitičkog i sintetičkog - pa zna da su to za čulnost prostor i vreme, za razum kategorije, a za um ideje. Kad se pomenu ideje kod Kanta, našem informisanom čitaocu je jasno da se pod tim misli pojam koji prevazilazi mogućnost iskustva,

termin „durch“ implicira slobodnost ne samo u eficijentnom, već i u teleološkom smislu. 
izveden iz nociona (čistog pojma koji svoje poreklo ima samo u razumu) ${ }^{4}$. Ideja predstavlja „pojam o totalitetu uslova za nešto što je dato kao uslovljeno“5 $\mathrm{i}$ to nužan pojam, koji u čulnosti nikada ne može imati potpuno podudaran predmet. Ideje su apsolutni, apriorni, od iskustva potpuno nezavisni, ničim uslovljeni pojmovi, koji su postavljeni samom prirodom uma. U teorijskoj ili spekulativnoj upotrebi uma, ideja nosi predznak „samo“ (nur), jer nikada ne može biti zaista data in concreto, već ostaje „problem bez ikakvog rešenja“. U praktičkoj pak upotrebi ideja ne samo što može biti data in concreto (,premda samo delimično“), već - štaviše - predstavlja nužan uslov svake praktičke upotrebe uma ${ }^{6}$.

Naš upućeni čitalac znaće da se transcendentalne ideje dele u tri klase (analogno trostrukosti mogućih odnosa predstava o kojima se može napraviti neka ideja): apsolutno jedinstvo misaonog subjekta, apsolutno jedinstvo niza uslova pojave i apsolutno jedinstvo uslova svih predmeta mišljenja uopšte, koje referišu na posebne ontologije Lajbnic-Volfove metafizike. Podrazumeva se da je tom čitaocu savršeno poznato da svakoj klasi ideja odgovara jedna klasa dijalektičkih zaključaka (ili „sofizama“ čistog uma): paralogizmi, antinomije i ideal. Dakako, čitalac zna i da Kant zapravo govori o ,antinomiji“, a ne antinomijama ${ }^{7}$, ali je nama lakše da

\footnotetext{
${ }^{4}$ Kant, Kritika čistoga uma, str. 209.

${ }^{5}$ Ibid., str. 210.

${ }^{6}$ Već je ovde jasno da um ima značaj pre svega kao praktički i da mu se u ime vrednosti koju ima za moralni život čoveka na neki način „opraštaju“ zablude koje proizvodi u spekulativnoj upotrebi. Ovaj rasap između dvaju funkcija uma neposredna je posledica razdvajanja zbiljnosti na ono fenomenalno i ono noumenalno, tj. Kantove nespremnosti da razliku postavi u pojam umesto u svest. Govoreći o antinomijama čistog uma, Hegel navodi: „Međutim, što stvari nisu protivrečne, već samosvest, za to Kantova filozofija ne haje; ne mari ništa (...) Kant ovde pokazuje suviše nežnosti prema stvarima; bila bi šteta kada bi one bile protivrečne. Što, međutim, duh (ono što je najuzvišenije) predstavlja protivrečnost, to navodno ne predstavlja neku štetu“ (Hegel, G. V. F., Istorija filozofije, III tom, BIGZ, Beograd 1975, str. 454).

${ }^{7}$ Kant pojam antinomije koristi u jednini, označavajući time jednu karakteristiku čistog uma, „neizbežnu i beskonačnu“, koja sadrži četiri para oprečnih tvrdnji, tj. teza i antiteza. Ovde će, radi preglednosti, svaki par oprečnih tvrdnji biti nazvan antinomijom. Elison s pravom navodi da je ,doslovno nemoguće preceniti značaj
} 
upotrebimo oblik množine. Takvom bi čitaocu, dakle, bilo sasvim prihvatljivo da tekst počne upravo od formulacija teze i antiteze u trećoj antinomiji te da izlaganje pretpostavlja kao poznato ne samo ovo što je napomenuto čisto primera radi, već i celinu i epohalni smisao Kantove filozofije. Stoga takav čitalac neće biti ni najmanje iznenađen narednim razmatranjima.

Kao što na paralogizmima počiva dijalektička psihologija, tako na antinomijama počiva - kako Kant kaže: „neka vajna“ - racionalna kosmologija. Na tragu tablice kategorija, Kant argumentuje da postoje samo četiri osnovne kosmološke ideje: apsolutna potpunost složenosti date celine svih pojava, apsolutna potpunost deljenja neke date celine u pojavi, apsolutna potpunost postanja neke pojave uopšte i apsolutna potpunost zavisnosti egzistencije onoga što se menja u pojavi ${ }^{8}$. Prve dve su kosmološke ideje u užem smislu (jer se odnose na svet kao matematičku celinu svih pojava), a druge dve su transcendentni pojmovi prirode (jer je priroda shvaćena kao dinamička celina). Ove četiri transcendentalne ideje predmetom su tzv. antitetike čistog uma. Antitetika se ogleda u „sukobu prividno dogmatičkih tvrđenja“ od kojih ni jedno ne može polagati pravo na istinitost, već su oba jednako verovatna i moguća, zbog čega ostaju nerazrešivim problemom samog čistog uma. Transcendentalna antitetika se otuda bavi ispitivanjem antinomija čistog uma, odnosno nastojanjem da se utvrde kako njeni uzroci, tako i rezultati i posledice koje ona ima po sam čisti um. Nas ovde interesuje apsolutna potpunost postanja neke pojave uopšte i način na koji se antitetika čistog uma prevazilazi u pogledu razumevanja problema slobode.

Kant navodi kako se mogu zamisliti samo dve vrste kauzaliteta: ili kauzalitet prirode ili kauzalitet slobode 9 . Kauzalitet prirode podrazumeva utemeljenu pravilnost kojom jedno stanje u čulnom svetu sledi za nekim

antinomije za Kantov kritički projekat" (Allison, H. E., Kant's Transcendental Idealism, Yale University Press, New Haven and London, 2004, p. 357).

${ }^{8}$ Kant, Kritika čistoga uma, str. 235.

${ }^{9}$ Ibid., str. 288. Ova disjunktivna odredba s početka odeljka o „Rešenju kosmološke ideje“" ne odgovara ipak u potpunosti smislu treće antinomije, kako će biti pokazano: u obe formulacije se naglašava da kauzalitet prirode svakako postoji, problematičan je samo kauzalitet slobode. 
prethodnim. Ovo prethodno stanje takođe je postalo, što znači da je i ono izazvano nekim uzrokom. S druge strane, sloboda $u$ kosmološkom smislu jeste „ona moć na osnovu koje može jedno stanje da počne samo od sebe, te njen kauzalitet, sa svoje strane, ne stoji prema prirodnom zakonu pod nekim drugim uzrokom koji bi ga određivao po vremenu“"10. Za razliku od kauzaliteta prirode, kauzalitet slobode nema nekog drugog uzroka izvan ili pre sebe, nema iskustvene prethodnice niti bilo čega sličnog: sloboda je „čista transcendentalna ideja“, koja ne počiva na iskustvu niti joj se predmet podudara sa bilo kakvim iskustvom ${ }^{11}$. Pošto „zakon mogućnosti sveg iskustva“" podrazumeva da sve mora imati neki uzrok, na osnovu čega se ne može dobiti apsolutni totalitet uslova u kauzalnom odnosu - um sebi stvara ideju nekog spontaniteta sposobnog da započne radnju sam od sebe. Ideja spontaniteta je sama sloboda: „Spontanitet čistog razuma bio bi potpuno nesupstancijalan i nerazumljiv pojam, kad bi čisti razum bio takoreći statičan princip, prazna čaura, apstrakcija. Spontanitet je praktička moć, koja razum označava kao stvaralački, koja ga čini dinamičkim principom" "12. Kant kaže da je „veoma važno“ što se na transcendentalnoj ideji slobode zasniva njen praktički pojam, jer je sama transcendentalna ideja zapravo „krivac“ za sve teškoće koje su se kroz povest javljale u pogledu mogućnosti, odnosno, nemogućnosti slobode.

Ovde su izuzetno važna dva pitanja. Prvo, zašto Kant o slobodi govori kao o kosmološkoj ideji? Drugo, zašto slobodu zasniva prevashodno kao transcendentalnu ideju, a potom na njoj temelji pojam praktičke slobode?

\footnotetext{
${ }^{10}$ Loc. cit.

11 „Pojam slobode je čist umni pojam, koji je upravo zato za teorijsku filozofiju transcendentan, tj. takav kome se ne može dati nikakav prikladan primer u bilo kojem mogućem iskustvu, koji, dakle, ne sačinjava nikakav predmet nekog nama mogućeg teorijskog saznanja, i naprosto ne može važiti kao konstitutivan, nego samo kao regulativan, i to, doduše, samo kao negativan princip spekulativnog uma, ali u praktičnoj upotrebi uma on dokazuje svoju realnost pomoću praktičkih načela“ (Kant, I., Metafizika morala, IKZS, Novi Sad 1993, str. 23).

${ }^{12}$ Kroner, R., Von Kant bis Hegel, J. C. B. Mohr, Tübingen 1961, S. 157, podv. M. Đ.
} 
Prvo pitanje se može i drugačije formulisati: zašto se sloboda razmatra u kosmologiji, a ne u psihologiji ${ }^{13}$ ? Podrazumeva se da je sloboda prerogativ ljudskog bića. Zbog čega onda nije razmatrana u odeljku o duševnosti? Ideje psihologije tiču se apsolutnog jedinstva misaonog subjekta, a ideje kosmologije apsolutnog jedinstva niza uslova pojave. Ma koliko jedinstvo niza uslova pojave u vlastitoj biti implicite sadržalo problem slobode, ne vidi se zbog toga još uvek zbog čega apsolutno jedinstvo misaonog subjekta ne podrazumeva pojam slobode. Uopšte, pitanja vezana za prvu, drugu i četvrtu antinomiju - ograničenost ili neograničenost sveta, jednostavnost ili složenost sveta i postojanje, odnosno, nepostojanje nekog nužnog bića - pripadaju u aristotelovskoj tradiciji ingerencijama prve filozofije (metafizike, teologije). Problem slobode je bitno praktički problem, koji se kod Aristotela razmatra u etici, ekonomiji i politici ${ }^{14}$.

Ono što Kanta primorava da problem slobode postavi pre svega kao kosmološki pojam, da bi iz njega izveo praktički pojam slobode, potiče iz nasleđa novovekovne filozofije i opšteg sukoba između determinizma i indeterminizma. U suprotnosti sa Aristotelovim teleološkim određenjem zbiljnosti, filozofija Novog veka u prvi plan stavlja pitanje eficijentnosti. Prirodu ona ne shvata u smislu Aristotelove physis. Za nju je priroda natura. Taj obrt podrazumeva i promenu u opštem načinu shvatanja zbiljnosti i odnosima među njenim različitim regijama. Dekart razliku između nužnosti i slobode izvodi iz razlike između dve supstancije. Nemogućnost njihovog posredovanja rezultuje u nemogućnosti zasnivanja

${ }^{13}$ Uostalom, i sam Kant kaže da se ,pitanje o mogućnosti slobode zaista tiče psihologije“ i dodaje ,ali pošto se ono zasniva na dijalektičkim argumentima čistoga uma, to mora zajedno sa svojim rešenjem da zanima jedino transcendentalnu filozofiju“ (Kant, Kritika čistoga uma, str. 289). Mora se primetiti da je transcendentalna filozofija jednako tako mogla dati odgovor na to pitanje u odeljku koji se tiče psihologije, da je to pitanje tamo postavljeno. Otuda je jasno da mora postojati još neki razlog za ovakvu odluku.

${ }^{14}$ Kod Aristotela, kao što je upućenom čitaocu poznato, područje teorijskog jeste područje onoga večnog, nenastalog, nepropadljivog, nužnog, etc., dok je područje praksisa sfera onoga budućeg i mogućeg. To znači da se i kod njega razdvajaju kauzalitet prirode i kauzalitet slobode, ali na taj način da je sloboda potpuno usidrena u praksis. Kant donekle ponavlja ovo rešenje, a donekle ga, na tragu novovekovne filozofije, modifikuje. 
praktičke sfere. Kod Spinoze se ta principijelna nemogućnost zaoštrava do te mere da je sve određeno kao samo jedna supstancija - deus sive natura - $\mathrm{u}$ kojoj je sloboda moguća samo kao spoznata nužnost. Sloboda je potpuno rastvorena u predstavi sveopšte i neizbežne nužnosti koja isključuje slobodu, ali i slučajnost. Lajbnicova prestabilirana harmonija explicite ostavlja prostora za neku vrstu spontaniteta monada, ali suštinski ponavlja avgustinovski problem posredovanja providnosti i slobode volje. Empirizam problem slobode tumači kao odsustvo prepreka, a u praktičkoj sferi vezuje slobodu prevashodno za svojinu (Lok) ili pravo jačeg (Hobs): „U modernijoj filozofiji problem slobode i determinizma nije postao predmet diskusije do sedamnaestog veka, principijelno u Spinozinom mišljenju a onda, eksplicitno u kontekstu problema determinizma, kod Džona Loka“"15.

$\mathrm{U}$ isto vreme, u novovekovnoj filozofiji ,ideja samosvijesti (kao spontanosti, samozakonodavstva ljudskog uma u teorijskom, praktičkom i

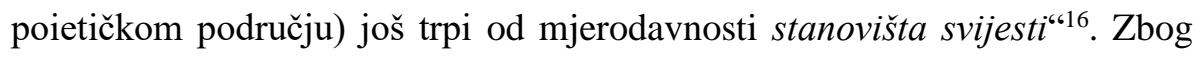
toga se u promišljanju metafizičkog, ali i praktičkog problema, drži u nerazrešivoj aporetici determinističke i indeterminističke pozicije. Kant uistinu po prvi put $\mathrm{u}$ istoriji filozofije problem slobode statuira kao eminentno metafizički problem. U opštem smislu, ovim se uvidom stvara pretpostavka za odgovor na pitanje o kosmologiji kao toposu eksplikacije problema slobode. Konkretnije, odgovor valja tražiti u Kantovoj rešenosti da spor reši na terenu na kome on i nastaje - u okviru pojma prirode shvaćenog kao natura! Aristotelovu physis bilo je moguće „naturalizovati“ eliminacijom finalnog uzroka (causa finalis), $\mathrm{tj}$. ideje svrhe, i favorizovanjem delatnog uzroka (causa efficiens). U takvoj „naturalizaciji“, sloboda nije mogla istaći svoje ontološko pravo u prirodi ni u čoveku kao delu prirode. U apsolutizaciji sistema kauzalne determinacije za slobodu nema mesta! Njen se visoki ontološki status može zadobiti i dokučiti samo na području ljudske svrhovite delatnosti. Nužno je stoga bilo problem slobode postaviti i razrešiti upravo na polju kosmologije kao eksplikacije modernog shvatanja prirode. Da je ovaj zaključak plauzibilan dokazuje i

\footnotetext{
15 Adorno, T., History and Freedom. Lectures 1964-65, Polity Press, Cambridge 2006, p. 193.

${ }^{16}$ Perović, M. A., Etika, INED CO „Media“, Novi Sad 2001, str. 304.
} 
sama Kantova distinkcija između kosmoloških ideja u užem smislu i transcendentalnih pojmova prirode. Sloboda i bog nisu pojmovi sveta, već pojmovi prirode!

Zašto Kant slobodu zasniva prvo kao transcendentalnu ideju, a tek potom iz nje izvodi praktičku slobodu? Delom je odgovoreno na ovo pitanje. Celina odgovora zahteva razrešenje treće antinomije. Sloboda $u$ kosmološkom smislu određena je kao moć na osnovu koje neko stanje može da počne samo od sebe. To je pozitivna odredba slobode. Sloboda u praktičkom smislu jeste nezavisnost volje od prinude. Tu se misli na unutrašnju prinudu od strane čula, a ne na neku spoljašnju prinudu: „Jer, jedna volja je utoliko čulna ukoliko je patološki (motivima čulnosti) aficirana; ona se zove životinjska (arbitrium brutum), ali može da bude patološki necesirana. Ljudska volja je zaista jedan arbitrium sensitivum, ali ne brutum, već liberum, jer čulnost ne čini njenu radnju nužnom, već čoveku pripada jedna moć na osnovu koje on može da se opredeli sam sobom, nezavisno od prinude od strane čulnih nagona“"17. Dakle, praktička sloboda se ovde pojavljuje kao negativna, kao sloboda od. Od mogućnosti pozitivne slobode suštinski zavisi ona koju smo odredili kao negativnu, odnosno, negativna sloboda u izvesnom smislu proizilazi iz pozitivne. Otuda se dokazivanjem da sloboda u kosmološkom smislu može postojati naporedo sa kauzalitetom prirode $u$ isto vreme dokazuje i da sloboda postoji u praktičkom smislu $^{18}$.

Kant vidi „prostor“ za slobodu u razlikovanju pojave i stvari po sebi. Preciznije, sama ta razlika je nužan uslov, tj. pretpostavka slobode: „Ako su

\footnotetext{
${ }^{17}$ Kant, Kritika čistoga uma, str. 288.

18 Međutim, praktički um je taj koji teorijski uopšte dovodi do antinomije, jer teorijski sam po sebi nikada ne bi mogao uvideti nešto drugo osim kauzaliteta prirode: „Da je praktički um tim pojmom (tj. pojmom slobode - M.Đ.) najprije spekulativnom umu postavio nerješiv problem, kako bi ga njime doveo u najveću nepriliku, to je već jasno iz toga što čovjek, budući da u pojavama ništa ne može razjasniti na osnovu pojma slobode, nego ovdje uvijek prirodni mehanizam mora sačinjavati rukovođ, nikada ne bi došao do te odvažnosti da u znanost uvede slobodu, da ćudoredni zakon i s njime praktički um nije došao do toga i da nam nije nametnuo taj pojam“ (Kant, Kritika praktičkog uma, Naprijed, Zagreb 1974, prim. uz $\S 6$, str. 63). Dakako, to je jedan isti um, samo je reč o teorijskoj, odnosno, praktičkoj upotrebi.
} 
pojave stvari po sebi, onda se sloboda ne može spasti“"19. Ukoliko između pojave i stvari po sebi ne bi bilo razlike, kaže Kant, tj. ako bi pojava već bila stvar po sebi (a prostor i vreme onda načini egzistencije stvari po sebi), rezultat bi bila antinomičnost svojstvena svim transcendentalnim idejama. Uslovi bi pripadali istom nizu kao ono što je uslovljeno, pa bi niz uslova nužno morao biti ili previše veliki za razum ili previše mali. Dualizam stvari po sebi i pojave ne treba da spasi samo mogućnost slobode, već i univerzalnost $\mathrm{i}$ nedeljivost uma $^{20}$. Pošto je ovde ipak reč o dinamičkim pojmovima uma, koji se ne bave veličinom predmeta već samo njegovom egzistencijom, može se apstrahovati od veličine niza uslova i posmatrati samo dinamički odnos niza uslova prema onome što je uslovljeno. Stoga, pravo je pitanje da li sloboda može postojati pored opštosti prirodnog zakona kauzaliteta, ili „kad kažemo: svaki događaj u svetu mora proizaći ili iz prirode ili iz slobode, da li je to onda jedan pravi disjunktivan stav ili su možda i priroda i sloboda mogle jednovremeno dejstvovati u jednome događaju, samo svaka u drugom smislu"21.

Ovde se javlja jedan specifičan problem. Kant nije potpuno dosledan - ili nije do kraja precizan - u svojoj analizi odnosa između dva načina kauzaliteta. Naime, navedena disjunktivna odredba, kao ni ona s početka odeljka („U pogledu onoga što se dešava mogu se zamisliti samo dve vrste kauzaliteta: ili kauzalitet prirode ili kauzalitet slobode") zapravo ne mogu biti disjunktivne, budući da se kauzalitet prirode uopšte ne dovodi u pitanje (što je očigledno u obe formulacije treće antinomije) ${ }^{22}$. Stoga odnos snaga nikako ne može biti međusobno isključujući. Sloboda ne može da isključi

${ }^{19}$ Kant, Kritika čistoga uma, str. 289. Ovde se vidi sličan pathos kao i u čuvenom Kantovom stavu da je morao da uništi znanje da bi dobio mesta za veru, naime: svojevrsni pathos fatalističke „,bespomoćnosti“. Sličnost je potpuno razumljiva, s obzirom da i ,prostor za veru“ i „spasavanje slobode“ počivaju na istoj temeljnoj pretpostavci o rasapu između pojave i stvari po sebi.

${ }^{20}$ Up. Beiser, F. C., The Fate of Reason, Harvard University Press, Cambridge, Massachusetss and London 1987, p. 8.

${ }^{21}$ Kant, Kritika čistoga uma, str. 289.

${ }^{22}$ Nije stoga neobično što se Timerman pita zašto transcendentalna sloboda izgleda apsurdno (Timmerman, J., ,Warum scheint transzendentale Freiheit absurd? Eine Notiz zum Beweis für die Antithesis der 3. Antinomie“", Kant-Studien, 91/2000, Walter de Gruyter, Berlin, S. 8) 
prirodu! Pitanje je samo da li sloboda može da postoji $u z$ prirodu, tj. da li priroda nužno isključuje slobodu. Naravno, u jednom navodu se govori o jedina dva vida kauzaliteta koji se mogu zamisliti, iz čega se ne može izvesti zaključak o egzistenciji bilo koga od njih, a u drugom je reč o tome da se priroda i sloboda (tj. bitak i trebanje, nužnost i sloboda) možda ne moraju isključivati, već mogu postojati naporedo. U oba slučaja se, u izvesnom smislu, zanemaruje osnovni stav transcendentalne analitike po kome svi događaji u čulnom svetu moraju, na osnovu nepromenljivih zakona prirode, stajati u opštoj vezi. U krajnjoj liniji, Kant je svestan problema: „Pitanje je, dakle, samo u ovome: da li se i pored toga u istoj posledici koja je već determinirana prirodom može naći i sloboda ili je ona potpuno isključena

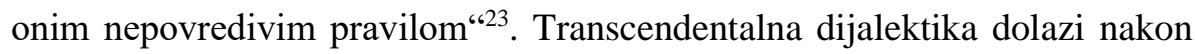
transcendentalne analitike i sabira njene uvide, što je očito i u formulaciji treće antinomije. Nije stoga jasno zašto Kant uopšte govori o disjunktivnom odnosu, kada je jasno da se pitanje mogućnosti slobode naspram prirode nikako ne može postaviti u disjunktivnom ,ili-ili“ (entweder-oder) odnosu, već jedino kao pitanje mogućnosti konjunktivnog, onoga ,¡“ (u smislu auch).

Kad ne bi postojala nesvodiva razlika između pojave i stvari po sebi, kauzalitet prirode bi za stvar po sebi važio jednako neumoljivo kao i za samu pojavu. S druge strane, ukoliko su pojave samo proste predstave čiji se međusobni odnosi temelje na empiričkim zakonima, mora se pretpostaviti da se one zasnivaju na nekim uzrocima koji sami nisu pojave pa onda ne mogu biti ni determinisani pojavama, bez obzira što se posledice takvih inteligibilnih uzroka pojavljuju i na taj način podležu determinaciji od strane pojava. To znači da su inteligibilni uzrok i princip njegovog kauzaliteta izvan niza empiričkih uslova, ali se same posledice nalaze u tom nizu: „Prema tome, posledica se, s obzirom na svoj inteligibilni uzrok, može smatrati za slobodnu, a ipak u odnosu prema pojavama može da se smatra tako kao da je iz njih proizašla iz nužnosti prirode“24. Može se reći da su

\footnotetext{
${ }^{23}$ Kant, Kritika čistoga uma, str. 289.

24 Ibid, str. 290. „Bez obzira na to kakav je naš pojam o slobodi volje s gledišta metafizike, njezine su pojave - ljudske radnje - jednako kao i sva druga prirodna zbivanja određene općim prirodnim zakonima” (Kant, I., „Ideja opće povijesti s gledišta svjetskoga građanstva” u: Kant, I., Pravno-politički spisi, Politička kultura, Zagreb 2000, str. 19).
} 
zapravo u pitanju nivoi zbiljnosti: na čulnom nivou je nezamisliv kauzalitet koji ne bi bio nužan i potpuno determinisan prirodom. Na inteligibilnom nivou, uzroci su slobodni. Dok god se ovi nivoi - ili regije - zbiljnosti ne mešaju, odnosno, dok god jedan od njih ne nastoji da uredi područje drugog, sloboda i priroda mogu egzistirati takoreći paralelno. Priroda, međutim, ne sme nastojati da se protegne na oblast onoga inteligibilnog, jer ona nad njim nema vlasti te ne može položiti računa o svojim postupcima. Posezanje prirodnog u inteligibilno ponovo priziva antinomiju. Jednako tako, sloboda nema šta da traži u regiji koja je pod vlašću prirode. „Ako hoćemo da idemo za varkom transcendentalnog realizma“, kaže Kant, „onda ne preostaju ni priroda ni sloboda“25. I zakoni prirode i zakoni slobode imaju svoje pravo, ali i nivoe na kojima to pravo mogu ispoljiti i ostvariti ${ }^{26}$. Samo pod tom pretpostavkom, $\mathrm{tj}$. samo pod pretpostavkom razdvojenosti regija zbiljnosti, čulnog i inteligibilnog, fenomena i noumena, moguće je razrešenje treće antinomije $\mathrm{u}$ korist teze ${ }^{27}$.

Ovo „sretno“ pomirenje kauzaliteta prirode i kauzaliteta slobode rezultuje vrlo nesretnim rascepljivanjem čoveka, tj. delatnog subjekta (handelnde Subjekt) na dve polovine, od kojih jedna pripada čulnom, a druga inteligibilnom svetu. Čovek je nosilac kako empiričkog karaktera - na osnovu koga njegove radnje stoje pod stalnim zakonima prirode i zajedno s drugim pojavama čine članove jednog niza ,prirodnog reda“ (Naturordnung)

\footnotetext{
${ }^{25}$ Kant, Kritika čistoga uma, str. 292.

${ }^{26}$ Naravno da čovek ima slobodu da skoči s krova obližnje zgrade u nameri da poleti. I naravno da priroda ,ima pravo“ da mu na to odgovori gravitacijom. Niko, međutim, neće tvrditi da je sloboda ograničena gravitacijom, niti da gravitacija gubi nešto od svog prava u susretu sa slobodom čoveka. (Podrazumeva se da se pod „gravitacijom“ misli na prirodni faktum, a ne na ljudsku interpretaciju tog faktuma. Jednako se tako podrazumeva da se letenje ovde odnosi na prirodnu (ne)osposobljenost čoveka da se kreće kroz vazduh bez pomagala, mašina i sličnog.) Uzrok skoka svakako je inteligibilne prirode (pošto se priroda više nego očigledno protivi ideji o čoveku kao letećem biću), ali njegova posledica je i te kako empirijska. Svaka regija ima svoj specifični obuhvat.

27 O ulozi uobrazilje u Kantovoj praktičkoj filozofiji vidi: Freydberg, B., Imagination in Kant's Critique of Practical Reason, Indiana University Press, 2005. Frajdberg ističe da ne samo što uobrazilja generiše pojam slobode i stvara $\mathrm{i}$ tezu i antitezu, već u konačnome ,postavlja“ meru za ovu antinomiju i omogućuje da sloboda ne bude isključena iz sveta (p. 29).
} 
- tako i inteligibilnog karaktera, na osnovu koga je on uzrok istih onih radnji kao pojava, ali sam ipak nije pojava jer ne stoji pod uslovima čulnosti. Čovek je nosilac „dva karaktera“: karaktera stvari u pojavi i karaktera stvari po sebi. - Spornost ovog određenja ne ogleda se u tome što je Kant čoveka odredio kao složeno biće. Naprotiv! Kantov čovek nije ni složen ni slojevit, on je raspolućen, kao što je raspolućena i sama zbiljnost ${ }^{28}$. Njegova dvostrukost ne može se posredovati, osim u slučaju da se kao posredovanje prihvati to što njegov inteligibilni karakter proizvodi empirijske posledice, što uistinu još uvek nije posredovanje, već postuliranje principa kauzaliteta na temelju pretpostavke hipotetičkog ako $p$, onda $q$, gde se ne objašnjava (po) čemu uopšte samo $p^{29}$. - „Čovek je jedna od pojava čulnoga sveta $\mathrm{i}$ utoliko je i on jedan od prirodnih uzroka čiji kauzalitet mora da stoji pod empiričkim zakonima. Prema tome, kao jedan takav uzrok čovek mora da ima neki empirički karakter isto tako kao i sve druge stvari u prirodi. (...) Međutim, čovek koji inače celu prirodu poznaje samo preko čula saznaje samoga sebe isto tako i pomoću čiste apercepcije... te je sam za sebe zaista, $\mathrm{s}$ jedne strane, phaenomenon, a, s druge, naime u pogledu izvesnih moći, jedan prost inteligibilan predmet, jer njegova radnja ne može da se pripiše receptivitetu čulnosti““30. Inteligibilnost čoveka, dakle, počiva na ,izvesnim moćima“. Te moći koje potkrepljuju pretpostavku o inteligibilnom karakteru čoveka jesu razum i um, i to pre svega um kao od čulnosti potpuno nezavisan i prema njoj u izvesnom smislu indiferentan ${ }^{31}$.

${ }^{28}$ „Moglo bi se reći, a da se pri tom ne učini veliko nasilje nad logikom Kantovog teksta, da je subjekt praktičkog uma, od samog početka, podeljeni subjekt“" (Zupančič, A., Ethics of the Real. Kant, Lacan, Verso, London-NY 2000, p. 21).

${ }^{29}$ U Kritici praktičkog uma (Predgovor, fusnota na str. 34-35) Kant navodi sledeće: „Sjedinjenje kauzaliteta kao slobode s kauzalitetom kao prirodnim mehanizmom, od kojih prvi stoji čvrsto pomoću ćudorednog zakona, a drugi pomoću prirodnog zakona, $\mathrm{i}$ to $\mathrm{u}$ jednom te istom subjektu, čovjeku, jest nemoguće, a da se on $\mathrm{u}$ pogledu prvoga ne predočuje kao bit sama po sebi, a u pogledu drugoga kao pojava, ono u čistoj, ovo u empirijskoj svijesti. Bez toga je protivurječje uma sa samim sobom neizbježivo“. Raspolućenost čoveka je neizbežna posledica opšte raspolućenosti sveta na pojavu i stvar po sebi.

${ }^{30}$ Kant, Kritika čistoga uma, str. 293.

31 ,Mi zovemo ove moći razum i um; naročito se um razlikuje potpuno i osobito od svih sila koje su empirički uslovljene, pošto on ispituje svoje predmete samo prema 
Dokaz da um ima sasvim osebujan kauzalitet (,ili bar da mi sebi predstavljamo neki kauzalitet na njemu“) jeste postojanje imperativa kao uzusa praktičkog života. Nansi s pravom tvrdi da ,imperativ obezbeđuje uslove mogućnosti praksisa ili je sam ono transcendentalno praksisa“32. Dokazivanje inteligibilnosti u potpunosti se temelji na činjenici egzistencije praktičkog sveta. Inteligibilni karakter čoveka je njegov praktički karakter: između ova dva termina bi se u Kantovoj filozofiji mogao staviti znak jednakosti. Da nije prakse, postavljanje razlike između pojave i stvari po sebi bilo bi u osnovi izlišno. Po Kantovom sudu, „u imperativu koji kazuje da treba nešto činiti izražava se jedna vrsta nužnosti i veza sa razlozima, veza kakva se inače nigde u prirodi ne pokazuje. Razum može o prirodi da sazna samo ono što u njoj jeste ili što je bilo ili što će biti. Nije moguće da u njoj treba da bude nešto drukčije nego što u svima ovim vremenskim odnosima u stvari jeste “33. Tražena differentia specifica između regija prirode i slobode, empiričkog i inteligibilnog karaktera jeste trebanje. $\mathrm{Ne}$ samo što se sfera praksisa odnosi na ono buduće i moguće - kao u Aristotelovom razumevanju praktičke filozofije - već na ono što treba $d a$ bude! Ono što treba da bude po svojoj je biti svakako buduće i moguće, ali se njegov pojam još uvek ne iscrpljuje tim dvema odredbama. Onom budućem i mogućem sad pridolazi odredba svojevrsne nužnosti, kao naloga uma da se u budućem delanju ima ozbiljiti tačno određena mogućnost i to ona koju sam um, potpuno oslobođen od svega empirijskog, propisuje kao ispravnu. Trebanje neposredno proizilazi iz samog praktičkog uma, tj. iz

idejama i po tome opredeljuje razum, koji najzad čini od svojih (doduše, takođe čistih) pojmova empiričku upotrebu“ (loc.cit.).

${ }^{32}$ Nancy, J. -L., Finite thinking, Stanford University Press, California 2003, p. 142.

${ }^{33}$ Kant, Kritika čistoga uma, str. 293. U nemačkom izvorniku stoji samo „Sollen“, te bi dakle prevod trebalo da glasi „U trebanju se izražava etc.“: „Das Sollen drückt eine Art von Notwendigkeit und Verknüpfung mit Gründen aus, die in der ganzen Natur sonst nicht vorkommt. Der Verstand kann von dieser nur erkennen, was da ist, oder gewesen ist, oder sein wird. Es ist unmöglich, daß etwas darin anders sein soll, als es in allen diesen Zeitverhältnissen in der Tat ist" (Kant, Kritik der reinen Vernunft, Werke in zwölf Bänden. Herausgegeben von Wilhelm Weischedel. Frankfurt am Main: Suhrkamp, 1977, Bd. 3, S. 498). 
slobode: „Trebanje je zapravo htenje, koje važi za svako umno biće pod uslovom ako bi um kod njega bez smetnji bio praktičan“34.

Pojmom trebanja Kant otvara novu epohu u povesti filozofije i samorazumevanja čoveka i njegove delatne biti. Za Helene je nezamisliva mogućnost izmeštanja praksisa iz onog bitkovnog: „Helenska je filozofija shvatala područje ljudskih žudnji, htijenja i djelanja u biti entelehijalno, kao područje usidreno u prirodnom bitku čovjeka, koji sam po sebi jeste čovjeku imanentno dobro, imanentni telos koji se ima slijediti, dokučivati i dostizati djelanjem (...) Mogućnost da se nekim zahtijevanim trebanjem pokuša ići preko entelehijalnog određenja čovjeka za antičku filozofiju ne samo da bijaše isključena, nego se nije ni mogla postaviti kao tematsko filozofskoetičko pitanje, budući da čovjek nije bio shvaćen kao radikalno modifikabilno biće, nego kao biće s prirodom koja mu je svojstvena ${ }^{\text {“35. }}$. Koncept modifikabilnosti čoveka postaje moguć tek sa hrišćanskom tematizacijom odnosa prve i druge prirode ${ }^{36}$, gde je čovek razumljen kao biće koje je - pod teretom istočnog greha - odvojeno od svoje istinske prirode, zbog čega čitav zemaljski život ima provesti u stremljenju ka povratku vlastitoj prvoj prirodi, tj. raju kao njenom mitskom iskonu. Ovo stremljenje se izražava nekim trebanjem u pogledu poštovanja božje volje i propisa crkve, ali to još uvek nije trebanje koje izvire iz slobode i ka slobodi smera, već naprosto koncept uvažavanja božje volje. Tek će novovekovna filozofija, a posebno Hjumov uvid o nemogućnosti da se vrednosni sudovi izvode iz indikativnih, otvoriti prostor za razumevanje ljudske biti ne samo kao modifikabilne, već kao one koja je u toj modifikabilnosti slobodna da sebi postavlja svrhe i prema njima samerava vlastiti bitak ${ }^{37}$. Taj otvoreni

\footnotetext{
${ }^{34}$ Kant, I., Zasnivanje metafizike morala, Dereta, Beograd 2004, str. 106. Pojam trebanja označava demarkacionu liniju između razuma i uma, teorije i prakse: „Zakonodavstvo pomoću pojmova prirode obavlja razum i ono je teorijsko. Zakonodavstvo pomoću pojma slobode sprovodi um, i ono je čisto praktično. Um može biti zakonodavan samo i jedino u oblasti prakse“" (Kant, Kritika moći suđenja, BIGZ, Beograd 1975, str. 66). To da je praktički um zakonodavan neposredno izvire iz ideje trebanja.

${ }^{35}$ Perović, M. A., Etika, str. 409.

${ }^{36}$ Pojam druge prirode osobito je značajan u Hegelovoj filozofiji.

37 Up. Hume, D., An Enquiry Concerning Human Understanding, University of Adelaide 2014, p. 40 et passim.
} 
prostor bio je pogodno tle za veliki obrt koji se događa u Kantovoj filozofiji, u kojoj će, zajedno sa jasnom distinkcijom između prirode kao područja onoga što jeste i slobode kao područja onoga što treba da bude, biti postavljena i ideja primata onoga što treba da bude nad onim što jeste, odnosno, primata trebanja nad bitkom, slobode nad prirodom, praktičkog uma nad teorijskim, rečju: slobode nad nužnošću. Dalekosežne posledice te transformacije ne umanjuje bitno činjenica da je Kant topos onog Sollen pronašao $u$ području noumenalnog $i$ strogo ga odvojio od područja fenomenalnog. U prvom koraku oslobađanja vlastite biti od bitkovne određenosti, samosvest praktičkog sveta nije ni mogla izbrisati tu granicu.

Sled po kome iz slobode izvire trebanje, na trebanju se zasniva praktički zakon, a kao forma tog zakona pred konačno umno biće postavlja imperativ, čini samu okosnicu Kantovog praktičkog projekta u kome je moralnost određena kao inteligibilnost. Čulnost može proizvesti samo uslovljeno htenje, nikada imperativ. Otuda ne može biti reči o slobodi u kontekstu empiričkog karaktera - on u potpunosti stoji pod zakonima prirode. Međutim, i sam taj empirički karakter određen je u inteligibilnom, tj. „načinu mišljenja“. Sve čovekove radnje podložne su zakonodavstvu prirode, vremenski ,unapred određene“ i nužne. Uzrok tih radnji nalazi se izvan domašaja prirode, $\mathrm{u}$ inteligibilnom karakteru čistog uma, koji je nezavisan od vremenskog i svakog drugog empirijskog uslova. Inteligibilni karakter je područje slobode, od njega potiču slobodni uzroci radnji, a te radnje u ispoljavanju pripadaju empiričkom karakteru čoveka. Ova sloboda „, ne može se smatrati samo negativno kao nezavisnost od empiričkih uslova (jer time bi moć uma prestala da bude jedan od uzroka pojava), već se može i pozitivno označiti kao neka moć koja može da započne neki niz događaja sama od sebe, tako da u njoj ništa ne počinje, već ona kao neuslovljeni uslov svake voljne radnje ne dopušta iznad sebe nikakve uslove koji joj u vremenu prethode, dok, međutim, njeno dejstvo ipak počinje u nizu pojava, ali ono tu

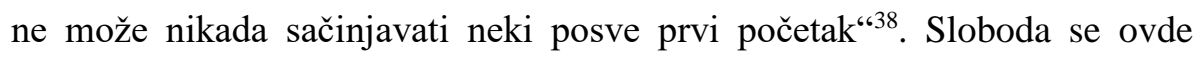
javlja u dvostrukosti svog negativnog i pozitivnog određenja, naime kao

38 Kant, Kritika čistoga uma, str. 296., podv. M. Đ. Nameće se analogija s Aristotelovim nepokrenutim pokretačem (Up. npr. Metafizika, 1015b 14-15). 
potpuna nezavisnost od čulnih uzroka i kao moć da se od sebe započne niz događaja.

Pozitivno određenje slobode pripada njenom kosmološkom, tj. ontološkom pojmu, a negativno praktičkom. Oba ova pojma izvode se iz inteligibilnog karaktera čoveka, a tek se njegove manifestacije u empiričkom karakteru (kao „šemi“ inteligibilnog) podvode pod opšte principe kauzaliteta prirode. U oba svoja određenja, sloboda je isključiva prerogativa inteligibilnosti, koja je izvan i pre svakog vremenskog odnosa. Ovaj inteligibilni karakter, kao umskost čoveka, uvek je prisutan u svim radnjama $\mathrm{i}$ - što je još važnije - uvek je isti: ono što može biti samo određujuće, a nikada određeno, nije podložno promenama, pa onda ,ne možemo postaviti pitanje: zašto se um nije drugačije opredelio, već samo: zašto on svojim kauzalitetom nije pojave drukčije determinirao?“39. Odgovor na ovo drugo pitanje takođe prevazilazi moć uma, pa čak i „svako njegovo ovlašćenje“ pri postavljanju pitanja. Doduše, razlika između ova dva pitanja deluje kao fini sofizam: nije da se um opredelio, nego je odredio pojave. Ukoliko um određuje pojave, podrazumeva se da se opredelio da ih odredi na izvesni način, u tome i jeste bit slobode. Ono što Kant hoće da kaže na tragu je glasovitog Heraklitovog stava da je (inteligibilni) karakter čoveku sudbina. U tome se svakako krije svojevrsni fatalizam koji dovodi u pitanje ideju slobodnosti inteligibilnog karaktera: on je sposoban da, nezavisno od čulnosti, sam od sebe započne neki niz događaja, ali ispada da nije sposoban da taj niz događaja započne drugačije nego što ih je započeo. Mogućnost da um ipak drugačije determiniše pojave počiva na ideji trebanja, kao kultivizaciji ljudskosti i subjektiviteta.

Jasno se pokazuje zbog čega Kant zasniva slobodu prevashodno kao transcendentalnu ideju. On sam kaže da u Kritici čistog uma nije imao nameru da dokazuje ni stvarnost ni mogućnost slobode, već samo to da sloboda ne protivreči kauzalitetu prirode. Nameru je opredmetio u slobodi kao „transcendentalnom pojmu prirode“: „Sloboda se ovde uzima samo kao transcendentalna ideja na osnovu koje um misli da apsolutno započne niz uslova u pojavi onim što je čulno neuslovljeno, ali on se pri tom zapliće u jednu antinomiju sa svojim sopstvenim zakonima koje propisuje empiričkoj

\footnotetext{
${ }^{39}$ Kant, Kritika čistoga uma, str. 297.
} 
upotrebi razuma. Da se ova antinomija osniva na jednom prostom prividu i da priroda ne stoji u sukobu sa kauzalitetom slobode, to je jedino što smo mogli učiniti i do čega nam je samo jedino i bilo stalo“40.

\section{CITIRANA LITERATURA}

Adorno, T., History and Freedom. Lectures 1964-65, Polity Press, Cambridge 2006.

Allison, H. E., Kant's Transcendental Idealism, Yale University Press, New Haven and London 2004.

Beiser, F. C., The Fate of Reason, Harvard University Press, Cambridge, Massachusetss and London 1987.

Freydberg, B., Imagination in Kant's Critique of Practical Reason, Indiana University Press, 2005.

Hegel, G. V. F., Istorija filozofije, III tom, BIGZ, Beograd 1975.

Hume, D., An Enquiry Concerning Human Understanding, University of Adelaide 2014.

Kant, I., Pravno-politički spisi, Politička kultura, Zagreb 2000.

Kant, I., Kritika čistoga uma, Dereta, Beograd 2003.

Kant, I., Metafizika morala, IKZS, Novi Sad 1993.

Kant, I., Prolegomena za svaku buduću metafiziku, Plato, Beograd 2005.

Kant, I., Zasnivanje metafizike morala, Dereta, Beograd 2004.

Kant, I., Kritika moći suđenja, BIGZ, Beograd 1975.

Kant, I., Kritika praktičkog uma, Naprijed, Zagreb 1974.

Kroner, R., Von Kant bis Hegel, J. C. B. Mohr, Tübingen 1961.

Nancy, J. -L., Finite thinking, Stanford University Press, California 2003.

Perović, M. A., Etika, INED CO „Media“, Novi Sad 2001.

Timmerman, J., „Warum scheint transzendentale Freiheit absurd? Eine Notiz zum Beweis für die Antithesis der 3. Antinomie“, Kant-Studien, 91/2000., Walter de Gruyter, Berlin.

Zupančič, A., Ethics of the Real. Kant, Lacan, Verso, London-NY, 2000.

${ }^{40}$ Ibid., str. 298. 


\title{
MINA ĐIKANOVIĆ \\ Faculty of Philosophy, University of Novi sad
}

\section{THE PROBLEM OF THE THIRD ANTINOMY}

\begin{abstract}
In this paper, author investigates the way Kant was trying to resolve the centuries-long discussion on the relation between nature and freedom. Along with paralogisms and the ideal, the antinomies represent "sophisms of the pure mind". The so-called third antinomy presents the conflict of the adverse views on the relation between nature and freedom, i.e. necessity and freedom. Kant believes that through disunion of the world he can reveal space for human freedom and be able to show that third antinomy will resolve itself in the manner that is not destructive for reality.
\end{abstract}

Keywords: Kant, antinomy, freedom, nature, mind, causality

Primljeno: 26.2.2021.

Prihvaćeno: 5.5.2021. 